\title{
Dopplerometric Parameters of Cerebral Blood Flow with Migraine
}

\author{
Abdullaiev R Ya ${ }^{1 *}$, Kalashnikov VI' ${ }^{1}$, Globa MV² and Posokhov NF $^{3}$ \\ ${ }^{1}$ Kharkiv Medical Academy of Postgraduate Education, Ukraine \\ ${ }^{2} A P$ Romodanov Institute of Neurosurgery at the Academy of Medical Sciences of Ukraine \\ ${ }^{3}$ Institute of Neurology, Psychiatry and Narcology of the National Academy of Medical Sciences of Ukraine, Ukraine
}

Submission: April 17, 2018; Published: May 04, 2018

*Corresponding author: Rizvan Yagubovich Abdullaiev, Department of Ultrasound Diagnostics of Kharkov Medical Academy of Postgraduate Education, Ukraine, Email: rizvanabdullaiev@gmail.com/rabdullaev@bk.ru

\section{Abstract}

Introduction: Migraine is a common disabling brain disorder. Approximately $1 \%$ of the world's population may have chronic migraine. Cerebral hemodynamics during different phases of the migraine attack demonstrate alterations in cerebral blood flow and perfusion, vessel caliber, cortical and sub-cortical function, underscoring that migraine pathophysiology is highly complex.

Objective: Transcranial dopplerography assessment of blood flow parameters in patients with migraine.

Materials and methods: A retrospective analysis of the results of TransCranial Dopplerography (TCD) of the middle cerebral artery and main cerebral veins was performed in 117 patients with migraine-54 with aura and 63 without aura. The age of the subjects was 18-43 years, among them 53 (45.3\%) men and 64 (54.7\%) women. The maximum Systolic Velocity (Vs), the Resistance and Pulsativity Indexes (RI, PI) in Middle Cerebral Artery (MCA); the maximum systolic velocity in Basal Vein of Rosenthal (BVR) and in the Direct Sinus (DS) were determined.

Results: According to MRI data, structural changes in white matter of the brain were detected in 19 (30.2\%) patients with migraine without aura ( $1^{\text {st }}$ group) and $28(51.9 \%)$ patients with migraine with aura $\left(2^{\text {nd }}\right.$ group). The Vs in MCA among patients of 1 st group averaged $127.9 \pm 6.8 \mathrm{~cm} / \mathrm{c}$ in the patients of $2^{\text {nd }}$ group $-61.7 \pm 5.7 \mathrm{~cm} / \mathrm{c}$, in the control group $-108.4 \pm 6.1 \mathrm{~cm} / \mathrm{c}$ respectively. The Vs in a patients of $1^{\text {st }}$ group were significantly higher than in patients of $2^{\text {nd }}$ group and control group (P1-2<0.001; P1-2<0.001). The value of Vs was significantly lower than in the control group (P2-3 <0.001). In the first group, the value of RI was significantly (P1-2<0.05) less than in the second group. The value of PI in patients with migraine with aura was significantly higher $(\mathrm{P}<0.05)$ than in the group with migraine without an aura and a control group. The highest systolic blood flow velocity and asymmetry in the basal vein of Rosenthal was noted in patients of $1^{\text {st }}$ group and amounted to $46.4 \pm 5.7 \mathrm{~cm} / \mathrm{s}$, in the $2^{\text {nd }}$ group $-27.8 \pm 4.6 \mathrm{~cm} / \mathrm{s}$, in the control group $-21.4 \pm 3.8 \mathrm{~cm} / \mathrm{c}$, respectively. The value of Vs among patients of $2^{\text {nd }}$ group with high reliability (P 2-1<0.01, P 2-3<0.001) exceeded the rate in patients of $1^{\text {st }}$ group and control group.

Conclusion: In patients with migraine without an aura in the fetal period, the systolic blood flow velocity in the middle cerebral artery increases, the resistance index decreases. In patients with migraine with aura, the greatest increase in systolic blood flow velocity in the direct sinus is observed.

Keywords: Migraine; Transcranial dopplerography; Middle cerebral artery; Basal vein of Rosental; Direct sinus; Vessel caliber; Cortical and Subcortical function; Pathophysiology; Causative trigger

Abbreviations: TCD: TransCranial Dopplerography; Vs: Systolic Velocity; RI: Resistance Indexes; PI: Pulsativity Indexes; MCA: Middle Cerebral Artery; BVR: Basal Vein of Rosenthal; DS: Direct Sinus; ICHD: International Classification of Headache Disorders; Vd: Diastolic Velocity; CGRP: Calcitonin Gene-Related Peptide

\section{Introduction}

Migraine is a common disabling brain disorder. Chronic migraine is the term that the International Classification of Headache Disorders (ICHD) uses to describe patients with frequent headaches, believed to be biologically migrainous [1]. In the classical sense, migraine implies a chronic headache without certain primary causes [2]. The name 'migraine' originally comes from the Greek word hemicrania, meaning 'half of the head', representing one of the most striking features of the condition: that in many cases pain only affects one half of the head. Equally commonly, however, pain is felt bilaterally, at the front or the back of the head, more rarely in the face, and rarer still in the body ('migrainous corpalgia'). The pain is generally throbbing in nature, and typically made worse by any form of movement or even modest exertion. The majority of migraine attacks are severe or at least moderately so [3].

According to Stone etal. [3], complaints of chronic headache account for about $20 \%$ of patients in neurological outpatient consultations [4]. Global studies suggest that approximately $1 \%$ of the world's population may have chronic migraine [5]. Chronic migraine imposes a substantial economic burden on 
society [6]. Despite the fact that for most people migraine is more a certain inconvenience than some dangerous condition, it is one of 40 risk factors that lead to disability all over the world. According to the World Health Organization for 2012, migraine ranks fourth among neurological disorders after a stroke, meningitis and epilepsy. In the United Kingdom, it ranks third after stroke and dementia, resulting in 230,000 DALY (a year with disability disability) being lost every year [7].

The effectiveness of migraine treatment depends on the accuracy of the diagnosis and the peculiarities of its manifestation. Management of chronic migraine is complex, and many patients are less susceptible to therapy [8].

Headache is one of the most common ailments; migraine is one of the most prevalent and disabling neurological disorders and cluster headache presents as one of the most excruciating pain disorders. Both are complex disorder characterized by recurrent episodes of headache. A key feature is that various triggers can set off an attack providing the opportunity to explore disease mechanisms by experimentally inducing attacks. This review summarizes neuroimaging and hemodynamic studies in human in provoked and spontaneous attacks of migraine and cluster headache. Cerebral hemodynamics during different phases of the migraine attack demonstrate alterations in cerebral blood flow and perfusion, vessel caliber, cortical and sub-cortical function, underscoring that migraine pathophysiology is highly complex. Migraine attacks might begin in diencephalic and brainstem areas, whereas migraine aura is a cortical phenomenon. In cluster headache pathophysiology, the hypothalamus might also play a pivotal role, whereas the pattern of cerebral blood flood differs from migraine. For both disorders, alterations of arterial blood vessel diameter might be more an epiphenomenon of the attack than a causative trigger. Studying cerebral hemodynamics in provocation models are important in the search for specific biomarkers in the hope to discover future targets for more specific and effective mechanism-based anti-headache treatment [9]. It is of interest to study the hemodynamic parameters of blood flow in the vessels of the brain during the attack and the interictal period of migraine.

\section{Objective}

To study the dopplerometric parameters of the blood flow in the middle cerebral arteries and the main veins of the brain during the attack and the migraine.

\section{Materials and Methods}

A retrospective analysis of the results of Transcranial Dopplerography (TCD) of the middle cerebral artery and main cerebral veins was performed in 117 patients with migraine - 54 with aura and 63 without aura. The age of the subjects was 18-43 years, among them 53 (45.3\%) men and 64 (54.7\%) women. All patients underwent clinical neurological examination. The intensity of cephalic syndrome was assessed using a visual analog scale and a headache diary filled out by the patient himself. To determine the severity of the condition at the time of attack we used the MIDAS scale that describes the degree of decrease in the functional activity of the patient with migraine.

The maximum Systolic Velocity (Vs), the end Diastolic Velocity (Vd), average systolic velocity (TAMX), the Resistance and Pulsativity indexes (RI, PI) in Middle Cerebral Artery (MCA); the maximum systolic velocity in Basal Vein of Rosenthal (BVR) and in the Direct Sinus (DS) were determined. The control group was composed of 47 patients with unchanged carotid arteries, normal blood pressure, without a cardiovascular disease and chronic headache. The age of the subjects was 21-39years, among them 21 men and 26women.

Dopplerography was conducted on a Ultima PA (RADMIR, Ukraine), Philips HD 11XE and Angiodin (BIOSS, Russia) device using a sector transducers with the frequency of $2 \mathrm{MHz}$; MRI General Electric, Signa HDI, 1.5T.

\section{Results}

According to MRI data, structural changes in white matter of the brain were detected in $19(30.2 \%)$ patients of the 1 st group and $28(51.9 \%)$ patients of the $2^{\text {nd }}$ group. On T2 MRI images, these changes were characterized by hyper intensive and on $\mathrm{T} 1$ - isointensive foci, ranging from 3 to $12 \mathrm{~mm}$ (Figure 1-2).

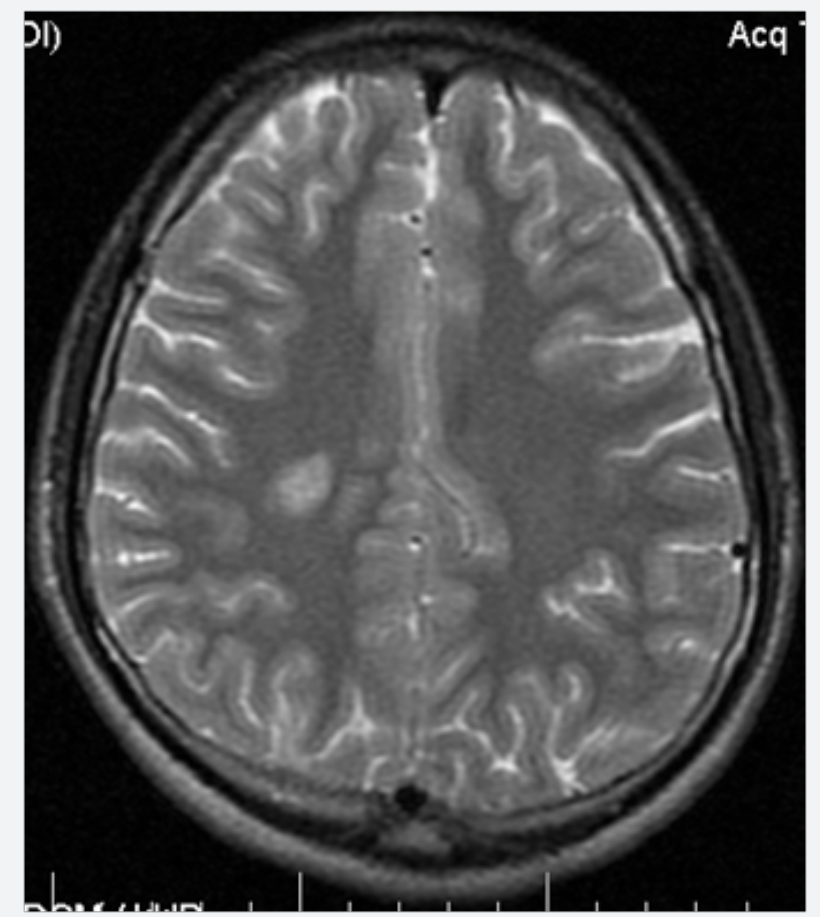

Figure 1: Axial T2 MR-tomogram. Hyperintensive focus in the white matter of the right frontal lobe. 


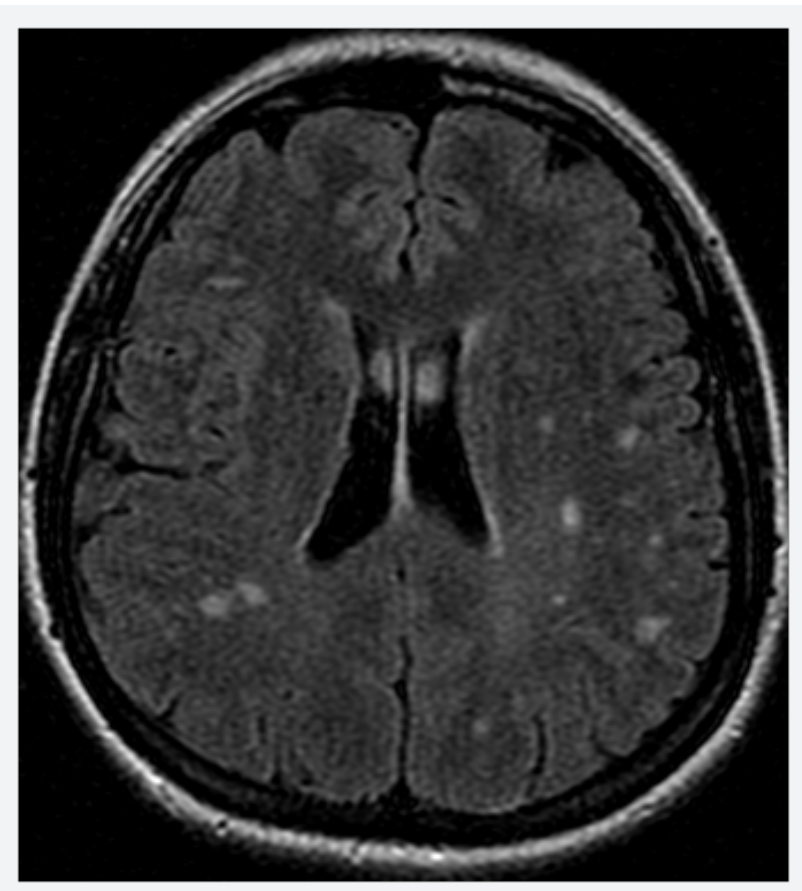

Figure 2: Axial T2 MR-tomogram. Multiple hyper intense foci in the white matter of the frontal and parietal lobes.

Table 1: Hemodynamic parameters of the blood flow in the MCA.

\begin{tabular}{|c|c|c|c|}
\hline $\begin{array}{c}\text { Doppler } \\
\text { Parameters }\end{array}$ & $\begin{array}{c}\text { Migraine } \\
\text { Without Aura } \\
(n=63) \\
1\end{array}$ & $\begin{array}{c}\text { Migraine with } \\
\text { Aura }(n=54) \\
2\end{array}$ & $\begin{array}{c}\text { Control Group } \\
(n=47) \\
3\end{array}$ \\
\hline Vs, см/с & $\begin{array}{c}127.9 \pm 6.8 \\
\text { P } 1-2<0.001 \\
\text { P } 1-3<0.05\end{array}$ & $\begin{array}{c}61.7 \pm 5.7 \\
\text { P } 2-3<0.001\end{array}$ & $108.4 \pm 6.1$ \\
\hline RI & $\begin{array}{l}0.53 \pm 0.02 \\
\text { P } 1-2<0.05\end{array}$ & $0.62 \pm 0.03$ & $0.59 \pm 0.03$ \\
\hline PI & $0.79 \pm 0.06$ & $\begin{array}{l}1.06 \pm 0.09 \\
\text { P } 2-1<0.05 \\
\text { P } 2-3<0.05\end{array}$ & $0.83 \pm 0.06$ \\
\hline
\end{tabular}

The maximum systolic blood flow Velocity (Vs) in MCA among patients with migraine without aura (I group) averaged $127.9 \pm 6.8 \mathrm{~cm} / \mathrm{c}$, in the second group of patients with migraine with aura $-61.7 \pm 5.7 \mathrm{~cm} / \mathrm{c}$, in the control group $-108.4 \pm 6.1 \mathrm{~cm} / \mathrm{c}$ respectively (Table 1). As seen from the Vs table, patients with migraine without aura were significantly higher than in patients with migraine with aura and control group (P1-2 $<0.001$; P1-2 <0.001). The value of Vs was significantly lower than in the control group (P2-3<0.001).

In the first group, the value of RI was significantly (P1-2 $<0.05$ ) less than in the second group. The value of PI in patients with migraine with aura was significantly higher $(\mathrm{P}<0.05)$ than in the group with migraine without an aura and a control group (Figure 3-4).

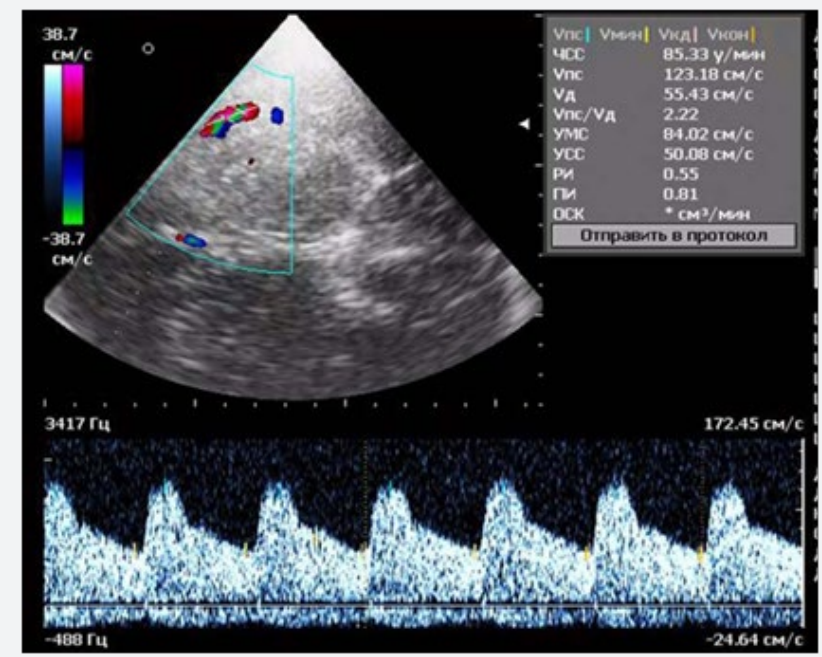

Figure 3: Transcranial dopplerography. 37years old women; Migraine without aura; Vs=123.18cm/c; RI-0.55; PI-0.81.

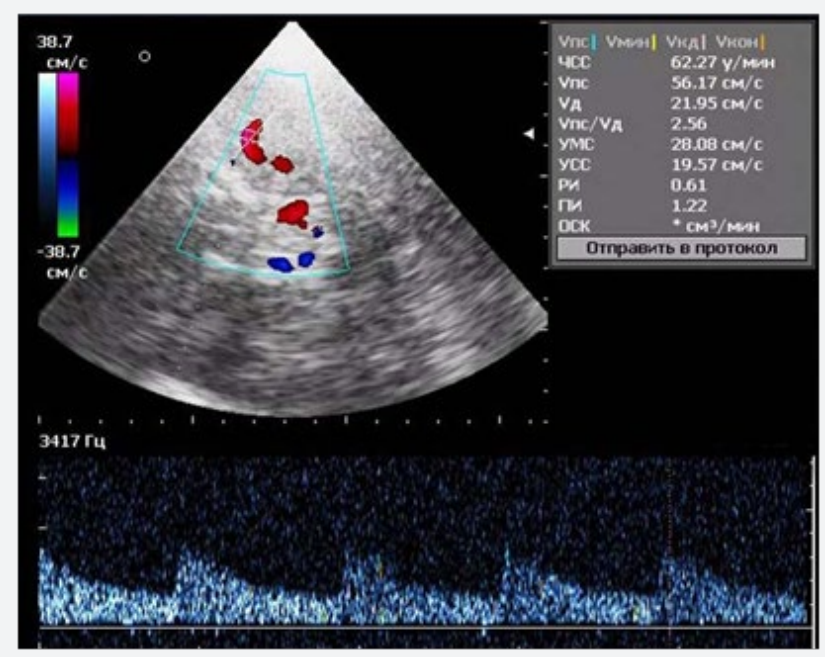

Figure 4: Transcranial dopplerography. 35years old women; Migraine with aura; Vs=56.17cm/c; RI-0.61; PI-0.122.

Table 2: Hemodynamic parameters of the blood flow in the main cerebral veins.

\begin{tabular}{|c|c|c|c|}
\hline $\begin{array}{c}\text { Doppler } \\
\text { Parameters }\end{array}$ & $\begin{array}{c}\text { Migraine } \\
\text { Without Aura } \\
(\mathrm{n}=63) \\
1\end{array}$ & $\begin{array}{c}\text { Migraine with } \\
\text { Aura }(n=54) \\
2\end{array}$ & $\begin{array}{l}\text { Control Group } \\
\qquad \begin{array}{c}(n=47) \\
3\end{array}\end{array}$ \\
\hline Vs, cm/c & $\begin{array}{c}127.9 \pm 6.8 \\
\text { P } 1-2<0.001 \\
\text { P } 1-3<0.05\end{array}$ & $\begin{array}{c}61.7 \pm 5.7 \\
\text { P } 2-3<0.001\end{array}$ & $108.4 \pm 6.1$ \\
\hline RI & $\begin{array}{l}0.53 \pm 0.02 \\
\text { P } 1-2<0.05\end{array}$ & $0.62 \pm 0.03$ & $0.59 \pm 0.03$ \\
\hline PI & $0.79 \pm 0.06$ & $\begin{array}{l}1.06 \pm 0.09 \\
\text { P } 2-1<0.05 \\
\text { P } 2-3<0.05\end{array}$ & $0.83 \pm 0.06$ \\
\hline
\end{tabular}

The blood flow in the main cerebral veins was characterized by a pronounced asymmetry in the hemispheres. The blood 
flow parameters in the Basal Vein of Rosenthal (BVR) and the Direct Sinus (DS) are presented in Table 2. The highest systolic blood flow velocity and asymmetry in the basal vein of Rosenthal was noted in patients with migraine with aura and amounted to $46.4 \pm 5.7 \mathrm{~cm} / \mathrm{s}$, in the second group $-27.8 \pm 4.6 \mathrm{~cm} / \mathrm{s}$, in the control group $-21.4 \pm 3.8 \mathrm{~cm} / \mathrm{c}$, respectively. As can be seen from the table, the value of Vs among patients with migraine with aura with high reliability (P 2-1<0.01, P 2-3 $<0.001)$ exceeded the rate in patients with migraine without an aura and control group (Figure 5-6).

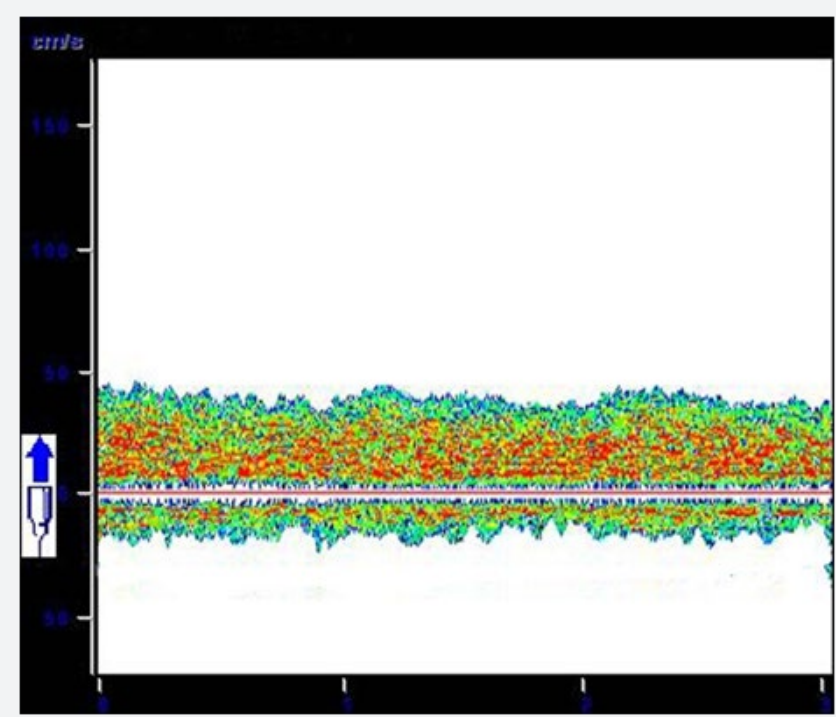

Figure 5: Doppler spectrum of blood flow in the basal vein of Rosenthal in a patient with migraine with aura. Vs- $48.2 \mathrm{~cm} / \mathrm{c}$.

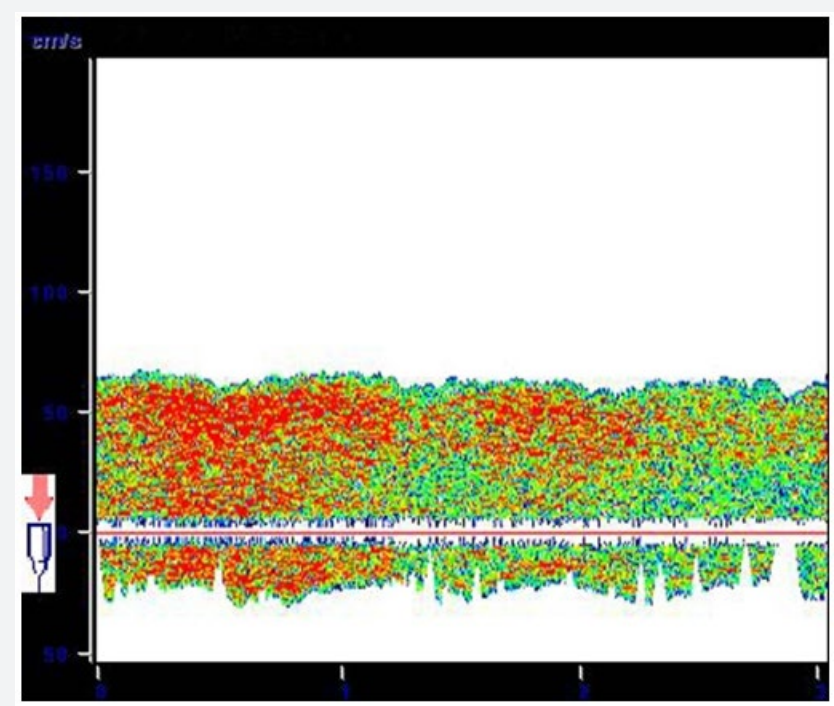

Figure 6: Doppler spectrum of blood flow in the direct sinus in a patient with migraine with aura. $V s-67.3 \mathrm{~cm} / \mathrm{c}$.

\section{Discussion}

In the work of Weatherall MW [4] analyzed clinical symptoms and methods of treatment of chronic migraine. Based on the studies carried out, the author draws conclusions that new acute and preventive options should become available over the next 3-6 years, including Calcitonin Gene-Related Peptide (CGRP) antagonists and antibodies, and drugs targeted at other serotonin receptor subtypes.

Lo MY et al. [10] conducted a literary analysis of hemodynamic changes in the vessels of the brain during acupuncture therapy of patients with chronic migraine. The conducted research allowed the authors to establish:

1. Acupuncture may positively influence not just dynamic, but also static cerebral auto regulation during the interictal phase, depending on the intervals between sessions of acupuncture as dose units;

2. TCD can detect pretreatment differences between responders and non-responders to acupuncture, which may be predictive of clinical response;

3. "Point-through-point" needling (at angles connecting acupoints) may be clinically superior to standard acupuncture, thus needling angles may affect treatment effectiveness.

In all the analyzed studies, there were no data reflecting hemodynamic changes in the vessels of the brain during the migraine attack.

In our work, hemodynamic data are presented not only in the middle cerebral artery, but also in the main veins of the brain.

\section{Conclusion}

In patients with migraine without an aura in the fetal period, the systolic blood flow velocity in the middle cerebral artery increases, the resistance index decreases. In patients with migraine with aura, the greatest increase in systolic blood flow velocity in the direct sinus is observed.

\section{References}

1. Saksena S, Merwade V (2015) Incorporating the effect of DEM resolution and accuracy for improved flood inundation mapping. J. Hydrol 530: 180-194.

2. Cook A, Merwade V (2009) Effect of topographic data, geometric configuration and modeling approach on flood inundation mapping. J. Hydrol 377(1-2): 131-142.

3. Ali AM, Solomatine DP, Baldassarre GD (2015) Assessing the impact of different sources of topographic data on 1-D hydraulic modelling of floods. Hydrol. Earth Syst. Sci 19: 631-643.

4. Hall JW, Tarantola S, Bates PD, Horritt MS (2005) Distributed sensitivity analysis of flood inundation model calibration. J. Hydraulic. Eng. 131 (2): 117-126.

5. Pappenberger F, Matgen P, Beven KJ, Henry JB, Pfister L, et al. (2006) Influence of uncertain boundary conditions and model structure on flood inundation predictions. Adv. Water Resour 29(10): 1430-1449.

6. Jung Y, Merwade V (2011) Uncertainty quantification in flood inundation mapping using generalized likelihood uncertainty estimate and sensitivity analysis. J Hydrol Eng 17(4): 507-520. 
7. Lin S, Jing C, Coles NA, Chaplot V, Moore NJ, et al. (2012) Evaluating DEM source and resolution uncertainties in the soil and water assessment tool. Stoch Env Res Risk Assess 27(1): 209-221.

8. Werner MGF (2001) Impact of grid size in GIS based flood extent mapping using 1-D flow model. Phys Chem Earth (B). 26(7-8): 517 522.

9. Haile A, Rientjes T (2005) Effects of Li DAR DEM Resolution in Flood Modelling: A Model Sensitivity Study for the City of Tegucigalpa, Honduras. ISPRS WGIII/3,III/4V/3 Workshop "Laser Scanning 2005" pp. 168-173.

10. Casas A, Benito G, Thorndycraft VR, Rico M (2006) The topographic data source of digital terrain models as a key element in the accuracy of hydraulic flood modelling. Earth Surf Proc Land 31(4): 444-456.

11. Sanders BF (2007) Evaluation of on-line DEMs for flood inundation modelling. Adv Water Resour 30(8): 1831-1843.

12. Schumann G, Matgen P, Cutler MEJ, Black A, Hoffmann L, et al. (2008) Comparison of remotely sensed water stages from LiDAR, topographic contours and SRTM. ISPRS J Photogramm Remote Sens 63(3): 283-296.

13. Patro S, Chatterjee C, Singh R, Raghuwanshi NS (2009) Hydrodynamic modelling of a large flood-prone system in India with limited data. Hydrol Process 23(19): 2774-2791.

14. US Army Corps of Engineers (2010) HEC-RAS River Analysis System Hydraulic Reference Manual. Version 4.1. Hydrologic Engineering Center, Davis, California pp.411.

15. Azizian A, Shokoohi AR (2015) Investigation of the Effects of DEM Creation Methods on the Performance of a Semi distributed Model: TOPMODEL. J Hydro Eng 20(11): 1-9.

16. Azizian A, Shokoohi AR (2015) Effects of Data resolution and stream delineation threshold effects on the results of a Kinematic Wave based GIUH model. Journal of Water SA 41(9): 61-70.
17. Azizian A, Shokoohi AR (2014) DEM resolution and stream delineation threshold effects on the results of geomorphologic-based rainfall runoff models. Turkish J Eng Env Sci 38(1): 64-78.

18. Brandt S (2005) Resolution issues of elevation data during inundation modeling of river floods. In: Proceedings of the XXXI International Association of Hydraulic Engineering and Research Congress (IAHR) pp. 3573-3581.

19. Bruner GW (2014) Combined 1D and 2D Modeling with HEC-RAS Version 5 Hydrologic Engineering Center, Davis, California pp. 130.

20. Laks I, Sojka M, Walczak Z, Wrózynski R (2017) Possibilities of Using Low Quality Digital Elevation Models of Floodplains in Hydraulic Numerical Models. Water 9(4): 283-300.

21. Kavanagh BF, Glenn Bird SJ (1996) Surveying principles and applications ( $4^{\text {th }}$ edn) Prentice Hall pp. 257-264.

22. Quiroga M, Popescu V, Solomatine I, Bociort L (2013) Cloud and cluster computing in uncertainty analysis of integrated flood models. J Hydroinf 15(1): 55-69.

23. Tarekegn TH, Haile AT, Rientjes T, Reggiani P, Alkema D (2010) Assessment of an ASTER generated DEM for 2D flood modelling. Int J Appl Earth Obs Geoinf 12(6): 457-465.

24. U.S. Army Corps of Engineers (2016). HEC-RAS River Analysis System 2D Modeling User's Manual. Version 5.0. Hydrologic Engineering Center, Davis, California pp.171.

25. Vaze J, Teng J, Spencer G (2010) Impact of DEM accuracy and resolution on topographic indices. Environ Model Softw 25(10): 1086-1098.

26. Wilson MD, Atkinson PM (2005) The use of elevation data in flood inundation modelling: a comparison of ERS interferometric SAR and combined contour and differential GPS data. Intl. J. River Basin Management 3(1): 3-20.

\section{Your next submission with Juniper Publishers will reach you the below assets}

- Quality Editorial service

- Swift Peer Review

- Reprints availability

- E-prints Service

- Manuscript Podcast for convenient understanding

- Global attainment for your research

- Manuscript accessibility in different formats

( Pdf, E-pub, Full Text, Audio)

- Unceasing customer service

Track the below URL for one-step submission https://juniperpublishers.com/online-submission.php 